\title{
Deoxycholate is an important releaser of peptide YY and enteroglucagon from the human colon
}

\author{
T E Adrian, G H Ballantyne, W E Longo, A J Bilchik, S Graham, M D Basson, R P Tierney, \\ I M Modlin
}

\begin{abstract}
Peptide YY (PYY) and enteroglucagon are hormonal peptides found in endocrine cells of the distal intestinal mucosa. Although it is known that plasma concentrations of both peptides increase in response to feeding, the mechanism by which ingested food causes release of colonic hormones is not understood. The release of PYY and enteroglucagon was measured in response to intraluminal stimuli in 176 patients having investigative colonoscopy. Introduction of air, saline (isotonic and hypertonic), glucose (isotonic and hypertonic), oleic acid (without bile salts), and casein hydrolysate all failed to release PYY but glucose caused a small but significant increase in enteroglycagon concentrations. In contrast with the lack of effect of nutrients, infusion of deoxycholic acid produced a rapid and marked dose responsive increase in plasma PYY concentrations when introduced into the sigmoid colon. PYY release was statistically significant at doses between $3.3 \mathrm{mM}$ to $30 \mathrm{mM}$; for example $10 \mathrm{mM}$ deoxycholate caused a sixfold increase in plasma PYY concentrations. Infusion of $10 \mathrm{mM}$ deoxycholate into the transverse colon or caecum produced an increase of PYY that was similar to the responses in the sigmoid colon. There was also a significant release of enteroglucagon in response to infusion of this bile salt into the sigmoid colon at doses between $3.3 \mathrm{mM}$ and $30 \mathrm{mM}$. The enteroglucagon response to 10 $\mathrm{mM}$ deoxycholate was similar in all three colonic regions. When oleic acid was added to deoxycholate as an emulsion, the release of PYY and enteroglucagon was similar to that seen with the bile salt alone. These findings suggest that bile salts may play an important part in the control of colonic endocrine function and may explain the increased circulating concentrations of colonic regulatory peptides that are seen in malabsorption states and after small bowel resection in humans.

(Gut 1993; 34: 1219-1224)
\end{abstract}

Peptide YY (PYY) and enteroglucagon are regulatory peptides localised to the endocrine cells of the mucosa of the distal intestine. ${ }^{12}$ Several reports have showed the coexistence of these two peptides in the same endocrine cell type, which has been named the $\mathrm{L}$ cell..$^{3-5}$ The genes producing these peptides are quite distinct but it is not clear whether both peptides are produced in all L cells, as dual localisation is only seen in a proportion of them. ${ }^{67}$ Indeed, tissue concentrations of enteroglucagon are highest in the terminal ileum, with smaller concentrations in the colonic mucosa, whereas by contrast PYY content increases distally with highest concentrations in the rectosigmoid region. ${ }^{89}$

Concentrations of PYY and enteroglucagon increase in response to feeding and the amount of increase in both hormones reflects meal size and content. ${ }^{89}$ Ingested fat and carbohydrate seem to be the most potent stimuli for these two peptides, and fatty acids introduced into the small intestinal lumen elicit a marked response..$^{8-12}$ When nutrients pass rapidly through the alimentary tract, as in the postgastrectomy dumping syndrome, there is a very rapid and substantial release of both PYY and enteroglucagon. ${ }^{1314}$ Similarly, circulating concentrations of both peptides are increased in conditions associated with malabsorption, such as sprue, or after small bowel resection. ${ }^{15-17}$ In the healthy and intact gastrointestinal tract, it is unlikely that substantial amounts of unabsorbed nutrients ever reach the colon in humans, and it is therefore likely that some other mechanism exists for the release of hormonal peptides from this region.

This study was designed to investigate the release of PYY and enteroglucagon, in response to a variety of intraluminal stimuli introduced endoscopically, to identify the mechanism for release of these colonic hormones in humans.

\section{Methods}

Studies were undertaken in 176 male patients who were having investigational colonoscopy and who were found to have a normal colon. In general, patients included in the study were either being screened because of guaiac positive stools, other symptoms of colonic disease, or for family history of colonic cancer, or as a follow up examination in patients with previous colonic polyps. Patients with abnormal findings at endoscopy or who had had previous surgery were excluded from the study. In particular, no patients with inflammatory bowel disease or cancer were studied. Informed consent was obtained from all participants, and the study had approval from the institutional human ethics committee. All patients received a traditional two day bowel preparation and were given clear liquids during this time. Patients drank a bottle of magnesium citrate each night and also received tap water enemas until the return was clear. If necessary, patients also received enemas the morning of the procedure. After an overnight fast of at least 10 hours, an 18 gauge catheter was placed in an antecubital vein for blood sampling. This was kept patent with heparinised isotonic saline (10 units/ml $0 \cdot 85 \%$ saline).

All colonoscopies were performed under the 
supervision of an experienced endoscopist. The position of the colonoscope was judged by topographical landmarks. The caecum was considered to be reached only if the light of the instrument was seen in the right lower quadrant, the base of the appendix was visualised, and the ileocaecal valve was seen. Similarly, the transverse colon was recognised by its characteristic triangular folds and the sigmoid colon by its circular folds. Infusions into the transverse colon were performed with the colonoscope about $10 \mathrm{~cm}$ proximal to the splenic flexure, while those into the sigmoid colon were done with the colonoscope about $10 \mathrm{~cm}$ proximal to the rectosigmoid junction. In an additional group of subjects $(n=4)$, the endoscope was passed through the ileocaecal valve into the terminal ileum for perfusion of oleic acid (24\%). Fluoroscopy was not used. In circumstances where the topography was not clear, patients received only sigmoid colon infusions. This was done particularly in patients where it was difficult to confidently identify the caecum.

Examination was begun without sedation. Patients were given meperidine (Demerol) or diazepam (Valium), or both intravenously if they experienced discomfort. Of the 176 patients who took part in the study, 67 received no drugs during endoscopy, 49 received Valium (mean dose $5.4 \mathrm{mg}$, range 2.5-10.0), 18 Demerol (mean dose $27 \mathrm{mg}$, range 10-50), and 42 Valium (mean dose $5.7 \mathrm{mg}$, range $2 \cdot 5-10.0$ ) and Demerol (mean dose $38 \mathrm{mg}$, range 10-100). Neither atropine nor glucagon were used in any of the patients. No antifoaming agents were used in the irrigation fluid.

One blood sample was taken before endoscopy and the patients then had a colonoscopy to the caecum. After their diagnostic procedure the colonoscope was positioned at site of infusion and a second blood sample collected. After a 10 minute period, a third blood sample was taken and $200 \mathrm{ml}$ of the air or respective test solution was introduced into the colon by steady infusion over a 10 minute period $(20 \mathrm{ml} / \mathrm{min})$. The test solutions were prepared in emulsion form by vigorous agitation of the components before administration. Test agents were infused through the biopsy channel of the colonoscope (F10I $133 \mathrm{~cm}$, Olympus). The lumen was kept constantly in view so that the position of the instrument did not change. Further blood samples were collected at 10,20 , and 30 minutes after the start of the infusion. After the last sample was collected, the colonoscope was removed and the patient allowed to recover from the procedure. Only one test was conducted in each patient. Patients were randomly allocated to groups for each test substance.

Table I shows the number of subjects who received each test substance, mean age, and the site of colonic infusion. Blood samples were collected into chilled tubes containing sodium EDTA (2 $\mathrm{mg} / \mathrm{ml}$ ) and aprotinin (Novo 400 $\mathrm{KIU} / \mathrm{ml}$ ). Tubes were centrifuged within 15 minutes, and the plasma was decanted and stored at $-20^{\circ} \mathrm{C}$ for subsequent radioimmunoassay.

Plasma PYY and enteroglucagon concentrations were measured by well characterised radio- immunoassays, which have previously been described in detail. ${ }^{89}$ Briefly, PYY was measured using an antibody (Y21) raised to pure unconjugated PYY. The antibody is $\mathrm{N}$ terminally directed and shows no significant cross reaction with the related peptides, pancreatic polypeptide, and neuropeptide Y. Antiserum at a dilution of 1:160000 bound approximately 50\% of the $\mathbf{1}$ fmol monoiodo-PYY, which was used as tracer. The tracer, prepared by conventional chloramine $T$ oxidation, was purified using isocratic reverse phase high pressure liquid chromatography. The assay detected changes between adjacent samples of $0.4 \mathrm{fmol} /$ tube (equivalent to $2.0 \mathrm{pM}$ in plasma) with $95 \%$ confidence (ID ID $_{5} ; 8 \mathrm{fmol} \mathrm{PYY} /$ tube)

Enteroglucagon was measured using an antibody (R59), which fully recognises pancreatic glucagon and enteroglucagon, the antibody being $\mathrm{N}$ terminally directed. Pancreatic glucagon concentrations were measured using a specific C terminal antiserum (RCS5). Enteroglucagon concentrations were therefore derived by subtracting pancreatic glucagon concentrations from the total glucagon concentrations measured with R59. The assays show no significant cross reaction with other related peptides (secretin, VIP, PHI, GRF, and GIP) and detected changes between adjacent samples of $0.2 \mathrm{fmol} /$ tube with $95 \%$ confidence (equivalent to $1 \mathrm{pM}$ enteroglucagon in plasma). The $\mathrm{ID}_{50}$ of R59 for glicentin and glucagon are $4.4 \mathrm{fmol} /$ tube and $4.6 \mathrm{fmol} /$ tube respectively. The $\mathrm{ID}_{50}$ of RCS5 for glucagon is $3.5 \mathrm{fmol} /$ tube. Monoiodoglucagon was prepared and purified as described above for PYY.

Statistical analysis of incremental hormone responses after test stimuli was carried out by two way analysis of variance (ANOVA), with substance and site as the two factors. The incremental area under the curve was calculated for the $\mathbf{3 0}$ minute period of stimulation in each individual patient by the trapezoid method, after subtraction of the mean basal for that patient. Planned comparisons of means of incremental areas were carried out using the multivariate

TABLE I Details of test substance, mean age of patient, and site of colonic infusion

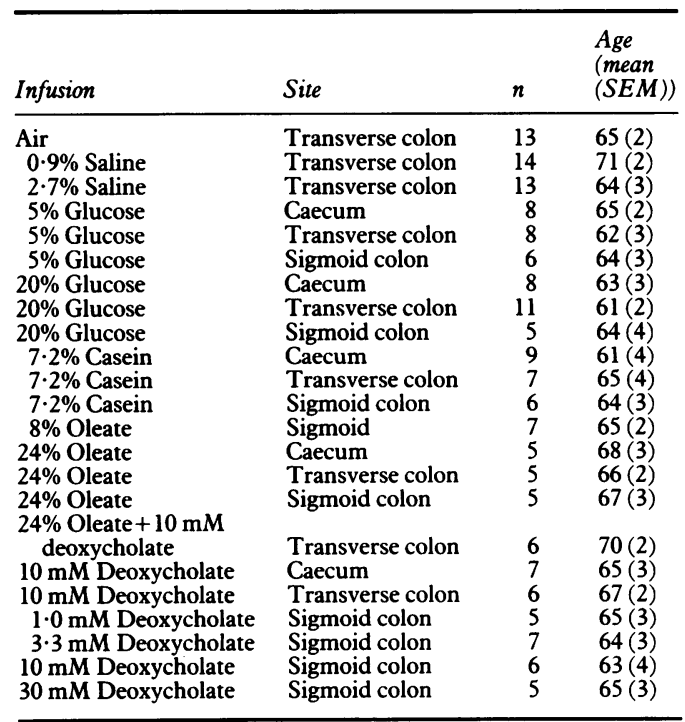


TABLE II Plasma PYY concentrations ( $p M$, mean (SEM)) before and after endoscopic infusion of $200 \mathrm{ml}$ of test substance into the caecum, transverse, or sigmoid colon in human volunteers

\begin{tabular}{|c|c|c|c|c|}
\hline Infusion & Region & $\begin{array}{l}\text { Before } \\
\text { colonoscopy }\end{array}$ & $\begin{array}{l}\text { Before } \\
\text { infusion }\end{array}$ & $\begin{array}{l}20 \text { min after } \\
\text { infusion }\end{array}$ \\
\hline Air & Transverse & $12 \cdot 5(1 \cdot 7)$ & $11 \cdot 8(1.9)$ & $13 \cdot 7(2 \cdot 3)$ \\
\hline $0.9 \%$ Saline & Transverse & $11 \cdot 5(2 \cdot 0)$ & $12 \cdot 3(2 \cdot 1)$ & $13 \cdot 6(2 \cdot 2)$ \\
\hline $2 \cdot 7 \%$ Saline & Transverse & $9 \cdot 4(2 \cdot 5)$ & $9 \cdot 7(2 \cdot 8)$ & $12 \cdot 8(3 \cdot 3)$ \\
\hline $5 \%$ Glucose & Caecum & $11 \cdot 8(3 \cdot 4)$ & $13 \cdot 7(3 \cdot 1)$ & $16 \cdot 0(2 \cdot 7)$ \\
\hline $5 \%$ Glucose & Transverse & $10 \cdot 6(2 \cdot 8)$ & $10.4(3.0)$ & $10 \cdot 1(2 \cdot 2)$ \\
\hline $5 \%$ Glucose & Sigmoid & $12 \cdot 0(3 \cdot 4)$ & $12 \cdot 0(2 \cdot 5)$ & $10 \cdot 2(1 \cdot 8)$ \\
\hline $20 \%$ Glucose & Caecum & $11 \cdot 0(3 \cdot 1)$ & $13 \cdot 1(2 \cdot 3)$ & $14 \cdot 4(2.9)$ \\
\hline $20 \%$ Glucose & Transverse & $11 \cdot 0(2 \cdot 4)$ & $12 \cdot 2(2 \cdot 9)$ & $11 \cdot 1(2 \cdot 9)$ \\
\hline $20 \%$ Glucose & Sigmoid & $10 \cdot 5(1 \cdot 8)$ & $11 \cdot 5(2 \cdot 3)$ & $11.6(1.9)$ \\
\hline $7 \cdot 2 \%$ Casein & Caecum & $10 \cdot 6(3 \cdot 5)$ & $12 \cdot 2(3 \cdot 8)$ & $14 \cdot 6(2.9)$ \\
\hline $7 \cdot 2 \%$ Casein & Transverse & $10.4(3.4)$ & $9 \cdot 8(2 \cdot 4)$ & $12 \cdot 0(2 \cdot 1)$ \\
\hline $7 \cdot 2 \%$ Casein & Sigmoid & $11 \cdot 6(3 \cdot 2)$ & $12 \cdot 0(2 \cdot 7)$ & $12 \cdot 0(4 \cdot 0)$ \\
\hline $8 \%$ Oleate & Sigmoid & $11 \cdot 6(2 \cdot 8)$ & $10 \cdot 7(2 \cdot 8)$ & $11 \cdot 7(2 \cdot 5)$ \\
\hline $24 \%$ Oleate & Caecum & $9 \cdot 3(3 \cdot 2)$ & $12 \cdot 2(3 \cdot 2)$ & $12 \cdot 1(2 \cdot 8)$ \\
\hline $24 \%$ Oleate & Transverse & $9 \cdot 2(2 \cdot 6)$ & $9 \cdot 0(2 \cdot 0)$ & $12 \cdot 2(3 \cdot 9)$ \\
\hline $24 \%$ Oleate & Sigmoid & $9 \cdot 8(2 \cdot 1)$ & $7 \cdot 5(1 \cdot 5)$ & $10 \cdot 0(2 \cdot 4)$ \\
\hline $24 \%$ Oleate $+10 \mathrm{mM}$ deoxychol & Transverse & $10 \cdot 0(1.5)$ & $10 \cdot 2(1 \cdot 1)$ & $52 \cdot 7(8 \cdot 2)$ \\
\hline $10 \mathrm{mM}$ Deoxychol & Caecum & $9 \cdot 1(1 \cdot 5)$ & $10 \cdot 2(1 \cdot 4)$ & $49 \cdot 9(5 \cdot 9)$ \\
\hline $10 \mathrm{mM}$ Deoxychol & Transverse & $10 \cdot 2(2 \cdot 2)$ & $12 \cdot 1(2 \cdot 4)$ & $66 \cdot 0(10 \cdot 7)$ \\
\hline 1.0 mM Deoxychol & Sigmoid & $12 \cdot 2(2 \cdot 9)$ & $13 \cdot 6(3 \cdot 4)$ & $33.6(11.9)$ \\
\hline $3.3 \mathrm{mM}$ Deoxychol & Sigmoid & $13 \cdot 4(2 \cdot 7)$ & $14 \cdot 7(2 \cdot 7)$ & $52 \cdot 5(23 \cdot 2)$ \\
\hline $10 \mathrm{mM}$ Deoxychol & Sigmoid & $9 \cdot 3(1.8)$ & $10 \cdot 8(1 \cdot 7)$ & $66 \cdot 5(7 \cdot 4)$ \\
\hline $30 \mathrm{mM}$ Deoxychol & Sigmoid & $8 \cdot 6(2 \cdot 3)$ & $9.4(1.0)$ & $62 \cdot 4(10 \cdot 5)$ \\
\hline
\end{tabular}

TABLE III Plasma enteroglucagon concentrations ( $p M$, mean (SEM)) before and after endoscopic infusion of $200 \mathrm{ml}$ test substance into the caecum, transverse, or sigmoid colon in human volunteers

\begin{tabular}{|c|c|c|c|c|}
\hline Infusion & Region & $\begin{array}{l}\text { Before } \\
\text { colonoscopy }\end{array}$ & $\begin{array}{l}\text { Before } \\
\text { infusion }\end{array}$ & $\begin{array}{l}20 \text { min after } \\
\text { infusion }\end{array}$ \\
\hline Air & Transverse & $18 \cdot 8(2 \cdot 6)$ & $16 \cdot 2(3 \cdot 0)$ & $17 \cdot 4(3 \cdot 1)$ \\
\hline $0.9 \%$ Saline & Transverse & $21 \cdot 6(2 \cdot 6)$ & $23 \cdot 6(2 \cdot 2)$ & $22 \cdot 4(2 \cdot 5)$ \\
\hline $2 \cdot 7 \%$ Saline & Transverse & $20 \cdot 0(1 \cdot 8)$ & $20 \cdot 5(2 \cdot 2)$ & $19 \cdot 8(2 \cdot 0)$ \\
\hline $5 \%$ Glucose & Caecum & $21.5(1.7)$ & $20 \cdot 9(2 \cdot 2)$ & $27 \cdot 0(3 \cdot 3)$ \\
\hline $5 \%$ Glucose & Transverse & $18 \cdot 4(3 \cdot 1)$ & $19 \cdot 1(2 \cdot 9)$ & $26 \cdot 4(3 \cdot 1)$ \\
\hline $5 \%$ Glucose & Sigmoid & $24.0(3.9)$ & $22 \cdot 0(4 \cdot 3)$ & $28 \cdot 6(4 \cdot 4)$ \\
\hline $20 \%$ Glucose & Caecum & $22 \cdot 3(3 \cdot 1)$ & $22 \cdot 9(2.9)$ & $26 \cdot 0(2 \cdot 2)$ \\
\hline $20 \%$ Glucose & Transverse & $17 \cdot 7(3 \cdot 0)$ & $16 \cdot 8(3 \cdot 3)$ & $20 \cdot 9(3 \cdot 2)$ \\
\hline $20 \%$ Glucose & Sigmoid & $19 \cdot 0(2 \cdot 8)$ & $19 \cdot 5(3.0)$ & $26 \cdot 0(3 \cdot 0)$ \\
\hline $7 \cdot 2 \%$ Casein & Caecum & $18 \cdot 8(1 \cdot 2)$ & $17 \cdot 4(1 \cdot 4)$ & $18 \cdot 2(1 \cdot 8)$ \\
\hline $7 \cdot 2 \%$ Casein & Transverse & $20 \cdot 0(2 \cdot 6)$ & $18 \cdot 2(2 \cdot 8)$ & $20 \cdot 7(3 \cdot 1)$ \\
\hline $7 \cdot 2 \%$ Casein & Sigmoid & $18 \cdot 8(2 \cdot 4)$ & $18 \cdot 0(2 \cdot 8)$ & $19 \cdot 1(3.0)$ \\
\hline $8 \%$ Oleate & Sigmoid & $24 \cdot 0(3 \cdot 2)$ & $23 \cdot 6(4 \cdot 7)$ & $24.6(3 \cdot 7)$ \\
\hline $24 \%$ Oleate & Caecum & $20.0(4.9)$ & $20 \cdot 1(4 \cdot 7)$ & $21 \cdot 0(4 \cdot 8)$ \\
\hline $24 \%$ Oleate & Transverse & $21 \cdot 4(4 \cdot 9)$ & $22 \cdot 4(5 \cdot 3)$ & $20 \cdot 8(3.9)$ \\
\hline $24 \%$ Oleate & Sigmoid & $19 \cdot 2(2 \cdot 7)$ & $23 \cdot 2(4 \cdot 5)$ & $22 \cdot 8(5 \cdot 4)$ \\
\hline $24 \%$ Oleate $+10 \mathrm{mM}$ deoxychol & Transverse & $18 \cdot 0(1 \cdot 6)$ & $18 \cdot 0(4 \cdot 1)$ & $32 \cdot 3(3 \cdot 5)$ \\
\hline $10 \mathrm{mM}$ Deoxychol & Caecum & $19 \cdot 9(3 \cdot 3)$ & $18 \cdot 4(3 \cdot 4)$ & $32 \cdot 1(4 \cdot 6)$ \\
\hline $10 \mathrm{mM}$ Deoxychol & Transverse & $18 \cdot 2(4 \cdot 3)$ & $17 \cdot 7(2 \cdot 6)$ & $31.5(3.7)$ \\
\hline 1.0 mM Deoxychol & Sigmoid & $23.6(1.4)$ & $23.4(1.9)$ & $23 \cdot 8(2 \cdot 3)$ \\
\hline $3.3 \mathrm{mM}$ Deoxychol & Sigmoid & $19.9(1.4)$ & $20 \cdot 3(1 \cdot 4)$ & $27 \cdot 0(1 \cdot 2)$ \\
\hline $10 \mathrm{mM}$ Deoxychol & Rectum & $20 \cdot 8(4 \cdot 7)$ & $22 \cdot 1(4 \cdot 4)$ & $38 \cdot 8(6 \cdot 2)$ \\
\hline $30 \mathrm{mM}$ Deoxychol & Sigmoid & $21 \cdot 6(1 \cdot 4)$ & $20.6(1.4)$ & $34 \cdot 4(0 \cdot 7)$ \\
\hline
\end{tabular}

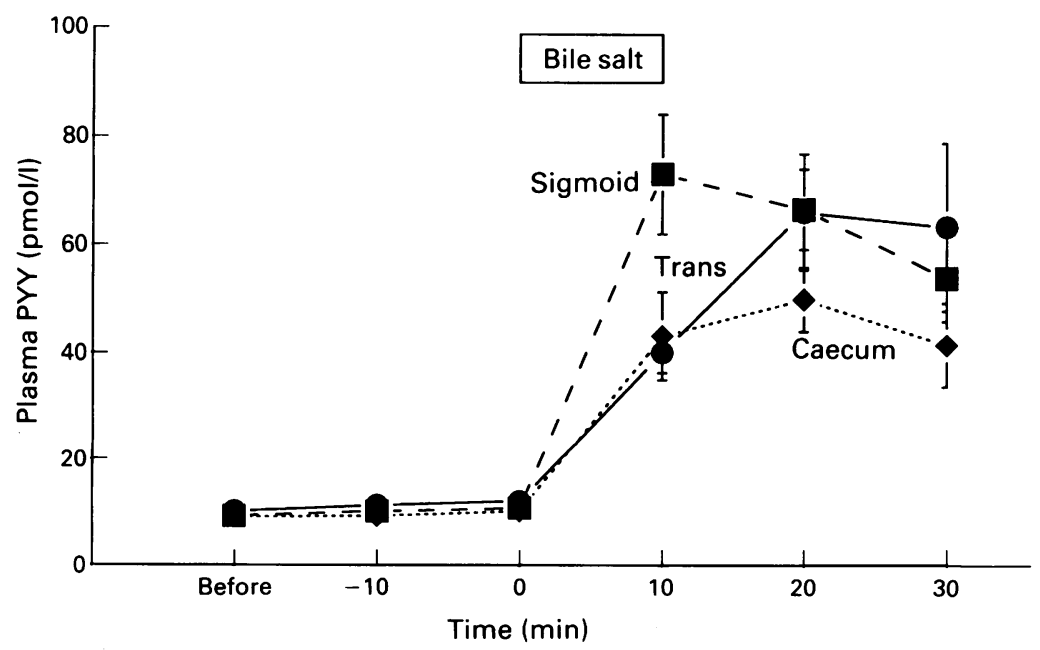

Figure 1: Plasma PYY concentrations during intracolonic infusion of $10 \mathrm{mM}$ deoxycholic acid into caecum, transverse colon (trans), and sigmoid colon respectively. Bile salt solution $(200 \mathrm{ml})$ was introduced into the colon over a 10 minute period through a colonoscope, beginning at 0 minutes. PYY concentrations were significantly increased by deoxycholate infusion at all three sites. general linear hypothesis to determine the substances that caused a significant increase in PYY and enteroglucagon concentrations from basal.

The dose effects of deoxycholate on the incremental responses of PYY and enteroglucagon were analysed by one way ANOVA, with significant individual dose effects determined by the multivariate general linear hypothesis. The dose effects of deoxycholate on the incremental responses of PYY and enteroglucagon were further analysed by linear regression analysis.

\section{Results}

Although the subjects could sense that the infusions were taking place, these were all tolerated well without significant side effects. Plasma PYY and enteroglucagon concentrations after air insufflation and intracolonic perfusion with saline, glucose, oleic acid, and amino acids (casein hydrolysate) are shown in Tables II and III respectively. There was no significant increase in concentration of either peptide after intracolonic infusion of any of these test substances, either given as isotonic or hypertonic solutions, except for a small effect of glucose on enteroglucagon concentrations. In contrast infusion of $10 \mathrm{mM}$ deoxycholate caused a substantial rise in circulating PYY and enteroglucagon concentrations (Figs 1 and 2). There were no significant differences in plasma PYY or enteroglucagon concentrations between patients who received sedation and those who received none (data not shown).

Because of the two factor experimental design (substance and site), two way analysis of variance (ANOVA) was carried out on the incremental hormone responses after the test stimuli. ANOVA showed a significant main effect of substance for PYY $\left(\mathrm{F}_{4,87}=119.5, \mathrm{p}<0.00001\right)$ and for enteroglucagon $\left(F_{4,87}=19 \cdot 4, p<0.00001\right)$, but not for site. Analysis of the effect of individual test substances showed that PYY was released significantly by deoxycholate (PYY incremental response (SEM) $36 \cdot 7$ (3.6) pmol/l/ $\left.\min , F_{1,87}=602 \cdot 7, p<0.00001\right)$ but not by any of the other test substances. Enteroglucagon was also released significantly by deoxycholate (incremental response $9.8(1.6) \mathrm{pmol} / \mathrm{l} / \mathrm{min}$, $\left.\mathrm{F}_{1,87}=131 \cdot 1, \mathrm{p}<0.00001\right)$ and glucose $(5 \%$ glucose: incremental response $4.3(0.6) \mathrm{pmol} / \mathrm{l} /$ $\min , F_{1,87}=28 \cdot 8, p<0.00001 ; 20 \%$ glucose: incremental response $3 \cdot 1(0.4) \mathrm{pmol} / 1 / \mathrm{min}$, $\mathrm{F}_{1,87}=15 \cdot 2, \mathrm{p}<0.0002$ ), but not by casein or oleate.

The incremental integrated release of PYY and enteroglucagon stimulated by infusion of deoxycholate into the sigmoid colon was dose dependent (Figs 3 and 4). A statistically significant release of PYY was seen only with the three highest doses of deoxycholate $(3.3 \mathrm{mM}$ : incremental response $32 \cdot 3(9 \cdot 1) \mathrm{pmol} / 1 / \mathrm{min}, \mathrm{F}_{1,19}=$ $18.9, \mathrm{p}<0.0004 ; 10.0 \mathrm{mM}$ : incremental response $46.4(7 \cdot 7) \mathrm{pmol} / \mathrm{l} / \mathrm{min}, \mathrm{F}_{1,19}=33 \cdot 4, \mathrm{p}=0.00001$; $30.0 \mathrm{mM}$ : incremental response $46 \cdot 4(7 \cdot 1) \mathrm{pmol} /$ $\left.1 / \mathrm{min}, \quad \mathrm{F}_{1,19}=28 \cdot 1, \quad \mathrm{p}=0.00004\right) \quad(\mathrm{Fig} 3)$. Similarly, statistically significant incremental responses of enteroglucagon to deoxycholate were found only for the three highest doses (3.3 mM: incremental response $4.9(1.2) \mathrm{pmol} / \mathrm{l} /$ 


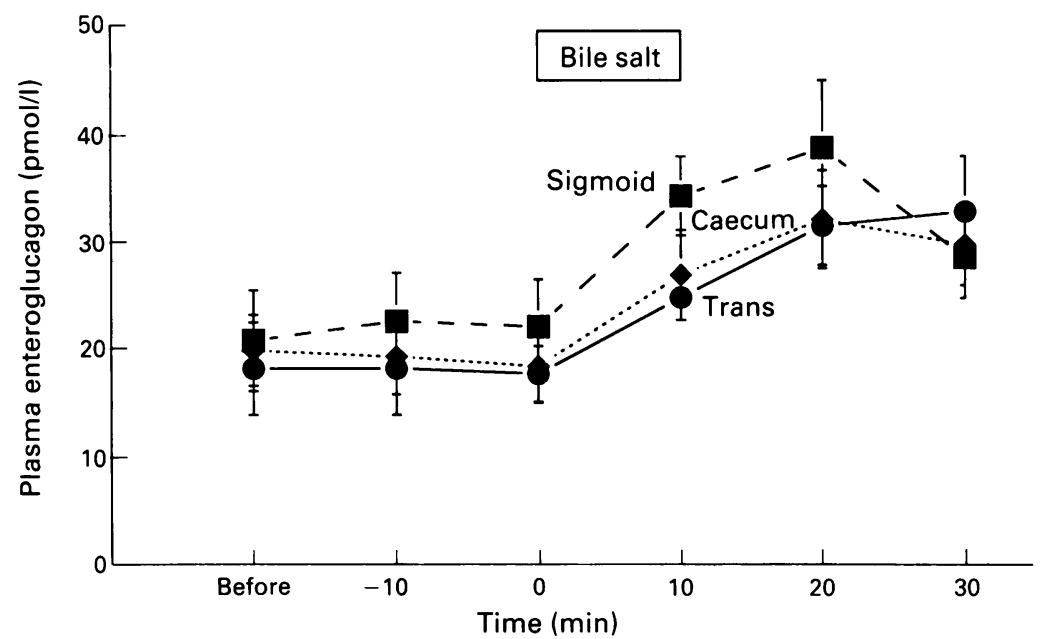

Figure 2: Plasma enteroglucagon concentrations during intracolonic infusion of $10 \mathrm{mM}$ deoxycholic acid into caecum, transverse colon (trans), and sigmoid colon respectively in human volunteers. Bile salt solution $(200 \mathrm{ml})$ was introduced into the colon over a 10 minute period, through a colonoscope, beginning at 0 minutes. Enteroglucagon concentrations were significantly increased by deoxycholate infusion at all three sites.

$\min , \mathrm{F}_{1,19}=6.8, \mathrm{p}<0.02 ; 10.0 \mathrm{mM}$ : incremental response $10.7(3.4) \mathrm{pmol} / \mathrm{l} / \mathrm{min}, F_{1,19}=27 \cdot 8$, $\mathrm{p}=0.00004 ; 30 \mathrm{mM}$ : incremental response $10 \cdot 1$ (1.6) $\mathrm{pmol} / \mathrm{l} / \mathrm{min}, \mathrm{F}_{1,19}=20 \cdot 9, \mathrm{p}=0.0002$ ) (Fig 4). The dose response areas under the curve were further analysed by linear regression analysis, which showed dose dependent effect for PYY $\left(F_{1,21}=8 \cdot 2, p=0.009\right)$ and enteroglucagon $\left(F_{1,21}\right.$ $=13 \cdot 6, \mathrm{p}=0 \cdot 001$ ).

When a high dose of oleic acid (24\%) was emulsified with $10 \mathrm{mM}$ deoxycholate, there was no significant difference in the magnitude of the PYY or enteroglucagon response from that seen with bile salt perfused alone (Tables II and III respectively).

Infusion of $200 \mathrm{ml}$ oleic acid (24\%) into the terminal ileum of four patients was without significant effect on plasma PYY and enteroglucagon concentrations. PYY concentrations were $15 \cdot 5(4 \cdot 4) \mathrm{pM}$ before the infusion and $16 \cdot 8$ $(5 \cdot 8)$ pM 20 minutes after the infusion began.

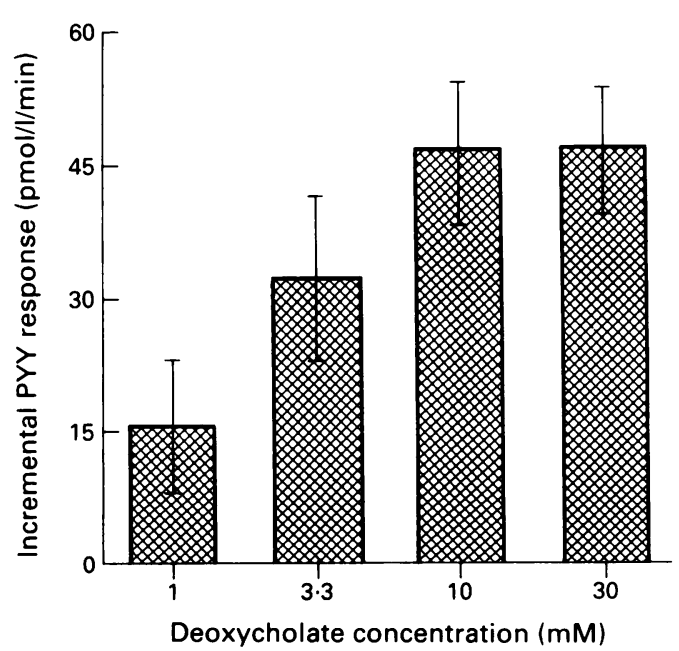

Figure 3: Incremental integrated response of plasma PYY concentrations representing the dose response to infusion of deoxycholate into the sigmoid colon during colonoscopy. PYY responses, measured as the incremental area under the curve, were significantly increased over basal at the three higher dose tested $(3.3 \mathrm{mM}, p<0.0004 ; 10 \mathrm{mM}, p=0.00001 ; 30.0 \mathrm{mM}$, $p=0 \cdot 00004)$.
Enteroglucagon concentrations were $17 \cdot 3(1 \cdot 5)$ pM pre-infusion and $13.8(4 \cdot 0)$ pM 20 minutes after the infusion began.

\section{Discussion}

High concentrations of PYY and enteroglucagon are found in the colonic mucosa of humans and other species. ${ }^{8-101819}$ The potent effects, particularly of PYY, on proximal gastrointestinal function would suggest an important hormonal role for these colonic peptides. ${ }^{11820-23}$ The mechanism by which they are released after the ingestion of food is, however, not understood. It is perhaps surprising that circulating concentrations of both peptides rise within 15 minutes after eating. ${ }^{89}$ Even if this early rise reflects release from the distal small intestine, it would seem too rapid to be as a result of the presence of unabsorbed nutrients. The secretion of these hormonal peptides, particularly from the colon, is therefore likely to involve other mechanisms. This study suggests that bile salt stimulation of the open type endocrine cells ( $\mathrm{L}$ cells) containing these peptides may represent such a mechanism. Indeed, the reported release of PYY and enteroglucagon by fat in the small bowel may be accounted for by the effects of the bile salts with which the fat was suspended. ${ }^{10}$ It should be noted that in the dog PYY release has been seen in response to intracolonic oleic acid in the absence of bile salts. ${ }^{24}$ In these studies, however, the rise in PYY concentrations was not detectable until the end of a one hour infusion of oleate in the colon, and the highest PYY concentrations were not seen until one hour after the infusion had finished. ${ }^{24}$ In contrast, intraduodenal oleate caused a substantial release of PYY at 30 minutes which reached a peak during the infusion at 60 minutes. ${ }^{24}$ These findings of a late response of PYY to intracolonic oleate suggest an indirect mechanism, rather than stimulation of the enteric endocrine cells directly by the luminal contents. Infusion of oleic acid into the ileoanal pouch in humans had no effect on circulating

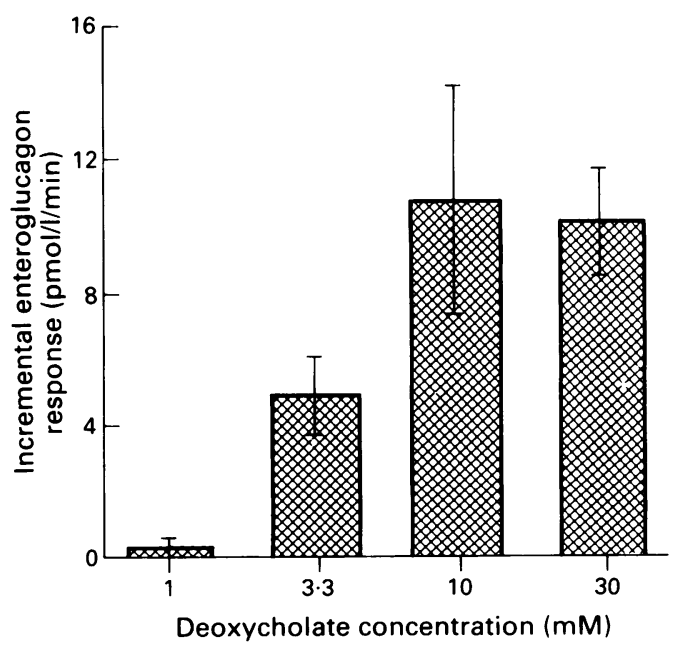

Figure 4: Incremental integrated response of plasma enteroglucagon concentrations representing the dose response to infusion of deoxycholate into the sigmoid colon during colonoscopy. Enteroglucagon responses, measured as the incremental area under the curve, were significantly increased over basal at the three higher doses tested $(3.3 \mathrm{mM}, p<0.02$; $10 \mathrm{mM}, p<0.00004$; and $30 \mathrm{mM} p<0.0003$ ). 
PYY concentrations, although a similar infusion did increase the PYY response to an oral mixed meal in these patients. ${ }^{25}$ Thus, species differences may exist in the mechanism of release of this peptide. Furthermore, studies in the isolated perfused rabbit colon have failed to show release of PYY by oleic acid, although this stimulus released enteroglucagon, and bile salts caused an appreciable increase in PYY concentrations. ${ }^{26}$ Oleic acid administration, at different doses, had no more effect on PYY release than the bile salt alone. ${ }^{26}$

The concentration range of deoxycholate used in these studies spans that normally found within the colonic lumen. Deoxycholate is the most abundant bile salt in the human colon and concentrations of $3.5(0.5) \mathrm{mM}$ have been reported in normal human stool. ${ }^{24}$ Furthermore, the higher concentrations used in this study reflect total bile salt concentrations in human colon. ${ }^{27}$

The concentrations of nutrients used in these studies are substantially higher than those which would normally be seen in the colonic lumen. It was felt that high concentrations would be more likely to cause direct stimulation of the enteric endocrine cells and thus to be effective. Additionally, it has been reported that circulating PYY concentrations are raised in patients with malabsorption and it was possible that high colonic fatty acid concentrations may be responsible for this exaggerated PYY release. ${ }^{16}$ The oleic acid concentrations used are in the range encountered in patients with steatorrhea. It is unlikely that low concentrations of nutrients would cause PYY release when high concentrations are without effect.

The magnitude of the rise in circulating PYY concentrations after deoxycholate perfusion in the human colon was similar to the rise reported after a normal meal. ${ }^{8}$ In healthy subjects the rise in plasma PYY was 4 (1) pM after a 530 calorie breakfast, 24 (5) after a 1200 calorie meal, and 49 (10) after ingestion of a large dinner. ${ }^{8}$ These rises were similar in magnitude to the effects of intracolonic deoxycholate in this study. The magnitude of the enteroglucagon response elicited by deoxycholate was similar to that reported for a test breakfast, measured using the same assay system. ${ }^{9}$

The release of colonic regulatory peptides by bile salts does make physiological sense. PYY slows gastric emptying and mouth to caecum transit in humans, and there is considerable circumstantial evidence to suggest that enteroglucagon is trophic to the small intestinal mucosa. ${ }^{21}{ }^{28}$ Release of these peptides by bile salts would thus tend to slow transit and increase absorptive mucosal surface area and would therefore lead to increased bile salt absorption in the terminal ileum. Thus a bile salt dependent release mechanism could represent a sensitive and important mechanism for controlling intestinal absorption by motor function and mucosal growth. The large increases in plasma concentrations of PYY and enteroglucagon that accompany such conditions as sprue or short bowel syndrome may represent an important adaptive response to malabsorption. It is likely, however, that factors other than bile salts are responsible for the massive rise in PYY and enteroglucagon that accompany coeliac sprue as bile salt malabsorption is not a feature of that disease.

Finally, manipulation of this potent release mechanism for PYY may ultimately prove to be clinically useful in patients who would benefit from slower intestinal transit, including patients with short bowel syndrome or major colonic resection.

The authors are grateful to Dr R D Reidelberger who provided expert advice on the statistical analysis of these studies.

1 El-Sahly M, Grimelius L, Wilander E, Ryberg B, Terenius L, Lundberg $\mathrm{JM}$, et al. Immunocytochemical identification of polypeptide YY (PYY) cells in the human gastrointestinal polypeptide YY (PYY) cells in the hur
tract. Histochemistry 1980; 77: 15-23.

2 Polak JM, Coulling I, Bloom SR, Pearse AGE. Immunofluorescent localisation of secretin and enteroglucagon in human intestinal mucosa. Scand $\mathcal{F}$ Gastroenterol 1971; 6 : $739-44$

3 Ali-Rachedi A, Varndell IM, Adrian TE, Gapp DA, Van Noorden S, Bloom SR, et al. Peptide YY (PYY immunoreactivity is co-stored with glucagon related immunoreactants in endocrine cells of the gut and pancreas. Histochemistry 1984; 80: 487-91.

4 Bottcher G, Sjolund K, Ekblad E, Hakanson R, Schwartz TW, Sundler F. Coexistence of peptide YY and glicentin immunoreactivity in endocrine cells of the gut. Regul Pept 1984; 8: 261-6.

5 Bottcher G, Alumets J, Hakanson R, Sundler F. Co-existence of glicentin and peptide $\mathrm{YY}$ in colorectal L-cells in cat and man. An electromicroscopic study. Regul Pept 1986; 13: man. An

6 Lund PK, Goodman RH, Dee PC, Habener JF. Pancreatic preproglucagon cDNA contains two glucagon-related coding sequences arranged in tandem. Proc Natl Acad Sci USA 1982; 79: 345-9.

7 Leiter AB, Toder A, Wolfe HJ, Taylor IL, Cooperman S, Mandel G, et al. Peptide YY, structure of the precursor and expression in exocrine pancreas. $\mathcal{F}$ Biol Chem 1987; 262 $12984-8$.

8 Adrian TE, Ferri G-L, Bacarese-Hamilton AJ, Fuessl HS, Polak JM, Bloom SR. Human distribution and release of a putative new gut hormone, peptide YY. Gastroenterology 1985; 89: $1070-7$.

9 Ghatei MA, Utttenthal LO, Christofides ND, Bryant MG, Bloom SR. Molecular forms of human enteroglucagon in tissue and plasma: Plasma responses to nutrient stimuli in health and in disorders of the upper gastrointestinal tract. health and in disorders of the upper gast

10 Aponte GW, Fink AS, Meyer JH, Tatemoto K, Taylor IL. Regional distribution and release of peptide YY with fatty acids of different chain length. Am $\mathcal{F}$ Physiol 1985; 249 G745-50.

11 Pappas TN, Debas HT, Chang AM, Taylor IL. Peptide YY release by fatty acids is sufficient to inhibit gastric emptying in dogs. Gastroenterology 1986; 91: 1386-9.

12 Read NW, McFarlane A, Kinsman RI, Bates TE, Blackhall $\mathrm{NW}$, Farrar GBJ, et al. Effect of infusion of nutrient solutions into the ileum on gastrointestinal transit and plasma levels of neurotensin and enteroglucagon. Gastroenterology 1984; 86: 274-80.

13 Bloom SR, Royston CMS, Thompson JPS. Enteroglucagon release in the dumping syndrome. Lancet 1972; ii: 789-91.

14 Adrian TE, Long RG, Fuessl HS, Bloom SR. Plasma peptide YY (PYY) in dumping syndrome. Dig Dis Sci 1985; 30 1145-8

15 Besterman HS, Bloom SR, Sarson DL, Blackburn AM Johnston DI, Patel HR, et al. Gut hormone profile in coeliac disease. Lancet 1978; i: 785-8.

16 Adrian TE, Savage AP, Bacarase-Hamilton AJ, Wolfe K, Besterman HS, Bloom SR. Peptide YY abnormalities in gastrointestinal diseases. Gastroenterology 1986; 90: 379-84.

17 Adrian TE, Savage AP, Fuessl HS, Wolfe K, Besterman HS, Bloom SR. Release of peptide YY (PYY) after resection of small bowel, colon or pancreas in man. Surgery 1986; 101: 715-9.

18 Lundberg JM, Tatemoto K, Terenius L, Hellström PM, Mut $\mathrm{V}$, Hökfelt $\mathrm{T}$, et al. Localization of peptide YY (PYY) in $\mathrm{V}$, Hökfelt T, et al. Localization of peptide YY (PYY) in
gastrointestinal endocrine cells and effects on blood flow and gastrointestinal endocrine cells and effects on blood fl
motility. Proc Natl Acad Sci USA 1982; 79: 4471-5.

19 Adrian TE, Bacarese-Hamilton AJ, Smith HA, Chohan P, Manolas KJ, Bloom SR. Distribution and postprandia release of porcine peptide YY. $\mathcal{F}$ Endocrinol 1987; 113: 11-4

20 Adrian TE, Savage AJ, Sagor GR, Allen JM, BacareseHamilton AJ, Tatemoto K, et al. Effect of peptide YY on gastric, pancreatic and biliary function in humans. Gastroenterology 1985; 89: 494-9.

21 Savage AP, Adrian TE, Carolan G, Chatterjee VK, Bloom SR Effects of peptide YY (PYY) on mouth to caecum intestina transit time and on the rate of gastric emptying in healthy volunteers. Gut 1987; 28: 166-70.

22 Pappas TN, Dedas HT, Taylor IL. Peptide YY: metabolism and effect on pancreatic secretion in dogs. Gastroenterolog 1985; 89: 1387-92.

23 Suzuki T, Nakaya M, Itoh Z, Tatemoto K, Mutt V. Inhibition 
of interdigestive contractile activity in the stomach by peptide YY in Heidenhain pouch dogs. Gastroenterology 1983; 85: 114-21.

24 Greeley GH, Hashimoto T, Izukura M, Gomez G, Jeng J, Hill FLC, et al. A comparison of intraduodenally and intracolonically administered nutrients on the release of peptide$\mathrm{YY}$ in the dog. Endocrinology 1989; 125: 1761-5.

25 Soper NJ, Chapman NJ, Kelly JA, Brown ML, Phillips SF, Go VLW. The 'ileal brake' after ileal pouch-anal Go VLW. The ileal brake after ileal

26 Ballantyne GH, Longo WE, Adrian TE, Vukasin A, Bilchik
AJ, Modlin IM. Deoxycholate stimulated release of peptide YY from the isolated perfused rabbit colon: a specific and non-neurally mediated mechanism. Am F Physiol 1989; 257: G715-24.

27 Owen RW, Thompson MH, Hill MJ, Wilpart M, Mainguet $P$, Roberfroid M. The importance of the ratio of lithocholic to deoxycholic acid in large bowel carcinogenesis. Nutr Cancer 1987; 9: 68-70.

28 Sagor GR, Ghatei MA, Al-Mukhtar MYT, Wright NA, Bloom SR. Evidence for a humoral mechanism after small intestinal resection. Gastroenterology 1983; 84: 902-6. 